\title{
EKSISTENSI SISTEM HUKUM PERIZINAN KEGIATAN PERTAMBANGAN DALAM OTONOMI DAERAH SEBAGAI SALAH SATU INSTRUMEN HUKUM HAK-HAK MASYARAKAT
}

\author{
David Aprizon Putra \\ Fakultas Hukum Universitas Muhammadiyah Bengkulu \\ Jl. Bali, Kp. Bali, Tlk. Segara, Kota Bengkulu \\ Email : davidaprizonputra@gmail.com
}

\begin{abstract}
Mining activity permit system would be the most urgent and most of its functions in maintaining the implementation of processing and protection of the environmental in Indonesia. For that purpose, it is expected the strengthening of the role of government, especially the local government as the owner of the mine producing areas. The ultimate goal of this course is for the benefit of mankind itself, society, state and nation of Indonesia. The permit system is desired able to preserve the rights of society as residents who has a wealth of space mining jurisdictions in general and the affected local communities in particular. After that the legality of permit system must have a strong substance of legal material used to be able to accommodate the interests and rights owned by the public. It is necessary to strengthen the quality of permits issued by the Regional Government in terms of safeguarding the rights of society-rich regions.
\end{abstract}

Keywords: Existence Mining Permit System, Regional Autonomy, Legal Instruments

\begin{abstract}
Abstrak
Sistem perizinan kegiatan pertambangan menjadi urgent dan paling besar fungsinya, dalam menjaga pelaksanaan pengolahan dan perlindungan lingkungan hidup Indonesia. Untuk tujuan itu, diharapkan adanya penguatan peran pemerintah khususnya pemerintah daerah sebagai pemilik daerah penghasil tambang. Tujuan capaiannya adalah untuk kepentingan manusia, kepentingan masyaraka, negara dan bangsa Indonesia. Sistem perizinan ini diinginkan mampu menjaga hak-hak masyarakat sebagai penduduk yang memiliki ruang wilayah hukum dalam kekayaan tambang secara umum dan masyarakat daerah setempat yang terdampak secara khusus. Setelah itu sistem perizinan secara legalitas harus memiliki substansi yang kuat secara materi hukum yang digunakan untuk mampu mengakomodir kepentingan dan hak-hak yang dimiliki masyarakat. Maka diperlukan penguatan kualitas perizinan yang dikeluarkan Pemerintah Daerah dalam hal menjaga hak-hak masyarakat daerah yang memiliki kekayaan.
\end{abstract}

Kata Kunci: Eksistensi Sistem Perijinan Pertambangan, Otonomi Daerah, Instrumen Hukum 


\section{A. Pendahuluan}

Sistem perizinan lingkungan dalam sistem perlindungan dan pengelolaan lingkungan hidup telah diamatkan dengan jelas dalam Undang-Undang Nomor 32 tentang Perlindungan dan Pengelolaan Lingkungan Hidup, Paragraf 7 bagian Perizinan, Pasal 36 yang berbunyi :

(1). Setiap usaha dan/atau kegiatan yang wajib memiliki amdal atau UKL-UPL wajib memiliki izin lingkungan.

(2). Izin lingkungan sebagaimana dimaksud pada ayat (1) diterbitkan berdasarkan keputusan kelayakan lingkungan hidup sebagaimana dimaksud dalam Pasal 31 atau rekomendasi UKL-UPL.

(3). Izin lingkungan sebagaimana dimaksud pada ayat (1) wajib mencantumkan persyaratan yang dimuat dalam keputusan kelayakan lingkungan hidup atau rekomendasi UKL-UPL.

(4). Izin lingkungan diterbitkan oleh Menteri, Gubernur, atau Bupati/ Walikota sesuai dengan kewenangannya.

Dari bunyi pasal di atas, maka lingkup perizinan lingkungan sejatinya bersifat kompleks dan holistik. Banyak berbagai permasalahan yang menjadi bagian di dalam masyarakat yang berkembang, baik bagian secara proses internal maupun eksternal. Secara umum kompleksitas berbagai permasalahan seputar pertambangan dan lingkungan tersebut memiliki penjabaranpenjabaran khusus (spesifik) masing-masin. Lingkungan hidup yang menjadi titik perhatian dan dibahas pada tulisan ini, yaitu mengenai izin lingkungan pada peruntukan wilayah kegiatan pertambangan. Menyoroti permasalahan pertambangan tidak akan lepas dari kata sumber daya alam (SDA), sumber daya manusia (SDM) dan menjadi sangat penting menjadi kata kuncinya (keyword) adalah teknologi.

Berbicara masalah sumber daya alam (SDA) maka konsentrasi pembahasan adalah membangun kemanfaatan kekayaan yang terkandung di dalam tanah yang memiliki kelimpahan tambang. Kapasitas ketersediaan yang menyimpan berbagai kekayaan alam, yang dibutuhkan dalam kehidupan kebutuhan hidup manusia. Kemanfaatan kekayaan yang terkandung di dalam bumi Indonesia, tentunya diharapkan dapat digunakan untuk hal kegunaan positif yang pada akhirnya akan berdampak positif, demikian halnya juga dengan upaya setelah usainya penggunaan dalam proses kemanfaatan kekayaan bumi dalam satu daerah.

Berbicara masalah sumber daya manusia, maka kita akan memiliki banyak para pengguna stake holders yang mengambil peranan dan menjadi pelaku dalam proses pengolahan di area pertambangan. Penyelenggara pemerintah pengambil kebijakan dengan kepemilikan kepentingan seharusnya bersinergi dengan masyarakat harus berjalan dengan satu tujuan bersma yaitu capaian kesejahteraan, bagi masyarakat daerah.

Semangat Reformasi yang digemakan pada tahun 1998, seharusnya menjadi dasar yang kuat terhadap perubahan tertib hukum dalam semua lini kehidupan berbangsa dan bernegara, yang diharapkan dapat memberikan dampak kesejahteraan pada sector pembangunan kehidupan ekonomi rakyat khususnya pengelolaan pertambangan. Demikian juga dengan asas demokrasi yang dianut, dapat diimplementasikan selayaknya amanat ...dari rakyat,oleh 
rakyat dan untuk rakyat... sejatinya dapat dilaksanakan secara benar dan bijak, tidak hanya sekedar memenuhi kuantitas kewajiban dan asal menggugurkan kewajiban bagi penyelenggara negara terhadap kehidupan bernegara dan rakyatnya. Ini berarti harus dapat meletakkan sesuai fungsi dari bentuk tanggungjawab antara siapa pihak yang manjadi tamu yaitu para pengusaha-pengusaha, baik pengusaha nasional maupun pengusaha dari negara lain, yang ingin bekerja sama dalam melakukan pemanfaatan dan pengelolaan lingkungan hidup yang terdapat di daerah pertambangan Indonesia, dan bagaimana meletakkan hak pemerintah serta rakyat, seharusnya dapat terpola pada pembagian yang berkesesuaian bukan pemerintah dan rakyat setempat mau menjadi budak didalam negerinya sendiri.

Penulis menganalogikan pengusaha sebagai tamu seharusnya mampu meletakkan diri secara baik dengan mampu memahami dan meletakkan fungsinya sebagai orang yang datang di daerah orang lain dengan etika, hingga dapat mengerti akan bentuk tanggungjawabnya secara hukum. Penulis memperhatikan secara cermat bahwa dalam 4 (empat) dekade terakhir, para pengusaha secara kepantasan perilaku hukum seharusnya patuh kepada pemerintah, kepada negara sebagai tamu, tetapi yang terjadi adalah sebaliknya malah menjadi tuan rumah di rumah orang dan daerah yang bukan merupakan wilayah hukumnya secara kehidupan berdaulat. Masyarakat, pemerintah seperti tidak punya kekuatan untuk berkuasa, itu menunjukkan ada kekeliruan dalam menguatkan ketentuan penerbitan dalam peraturan hukum pengelolaan wilayah tambang dalam daerah dan pemerintah sebagai penyelenggara wilayah hukum yang berdaulat dalam konsep etika perilaku hukum dan penegakkan hukum terhadap peraturan pertambangan.

Pemerintah dalam hal ini adalah sebagai pemegang kuasa atas semua sumber daya alam (SDA) yang ada, harusnya mampu melakukan penguasaan dengan baik dalam konteks memiliki, memanfaatkan, mengolah dan melindungi, sebagaimana amanat yang tercantum dalam Undang-Undang Dasar Negara Republik Indonesia tahun 1945. Pemerintahan Republik Indonesia dan Pemerintah daerah dengan kewenangan yang dimilki sekarang harus menjalankan amanah tersebut dengan baik, terlebih pemerintah daerah, dengan kewenangan Otonomi Daerah sekarang memiliki peran luas dan tentunya berat dalam mempertanggungjawabkan amanah tersebut kepada Rakyat yang memiliki kedaulatan atas negeri bernama Indonesia.

Terkait pengaruh kemanfaatan (convergance) teknologi, Prof. Dr. M. Daud Silalahi, $\mathrm{S} . \mathrm{H},{ }^{1}$ beliau membuat suatu penjelasan yang sangat beralasan (reasonable) terkait pengaruh teknologi terhadap masalah lingkungan hidup, berikut penjelasan bagan dari adanya kemanfaatan teknologi berikut ini :

Guru Besar Fakultas Hukum Universitas Padjadjaran, disampaiakan pada perkuliahan : hari senin, 30 september 2013 di Gedung Perkuliahaan Komar Kantaatmadja-Lantai 2.2 Fakultas Hukum Universitas Padjadjaran- Jalan Banda, Pukul 15.00-16.40 WIB. 
Bagan 1.

Pengaruh Teknologi Terhadap Masalah Lingkungan Hidup

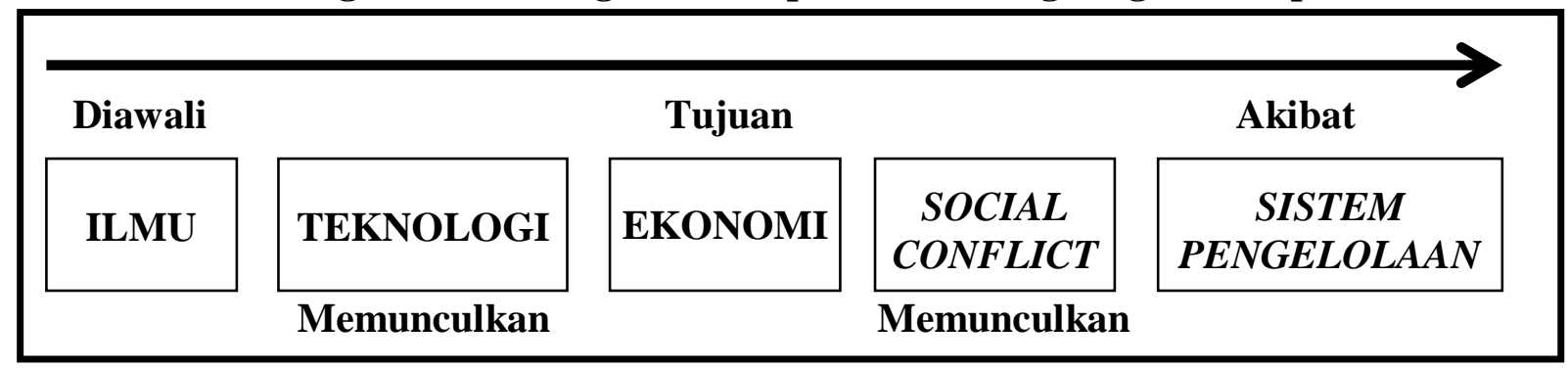

Berdasarkan bagan diatas, maka peran dari teknologi sangatlah sentral. Pencapaian tujuan ekonomi yang dilandasi oleh kemampuan teknologi yang mumpuni, tentunya tidak akan menimbulkan konflik sosial yang berarti. Sehingga menyebabkan upaya pengelolaan lingkungan hidup juga tidak akan menjadi terlalu berat. Semakin tinggi kemutakhiran teknologi yang digunakan, tentunya akan semakin sedikit pula dampak negatif lingkungan yang diakibatkan. Begitu pula sebaliknya, tetapi teknologi bukan hanya semata menjadi tolak ukur utama, para stake holders yakni pemerintah dan khususnya pihak pertambangan, harus pula benar-benar mematuhi aturan yang ada dengan berkomitmen sebaik-baiknya dalam menjaga kualitas lingkungan hidup.

Tata Ruang/ Wilayah (RT/RW), Analisis Mengenai Dampak Lingkungan (AMDAL), izin lingkungan dan izin kegiatan merupakan rumpun ikatan yang saling mengikat dan saling mempengaruhi dengan kuat satu sama lain. Ditambah lagi, dengan instrumen baru dalam sistem perizinan lingkungan, yaitu Kajian lingkungan Hidup Strategis (KLHS). Sejatinya harus sudah kuat dalam prinsip hukum bagi pemilik area pertambangan, untuk melaksanakan pengelolaan dan pemanfaatan sumber daya alam yang ada, sekaligus kita sebenarnya juga sudah mampu untuk melindungi sumber daya alam dan lingkungan kita.

Dalam pelaksanaannya, bahwa ternyata banyak terjadi tumpang tindih (overlapping) dan konflik atas kebijakan yang ada. Terjadinya tumpang tindih peraturan dan ketentuan undangundang atas kebijakan pemerintah daerah itu tanpa disadari telah melahirkan permasalahan hukum di lapangan. Padahal secara sistem peraturan hukum perundang-undangan, Pemerintah Indonesia dibidang hukum sudah memiliki kerangka pola pengaturan yang sangat baik dan kuat.Walaupaun sebenarnya masih jauh dari kata sempurna, merupakan suatu kewajaran karena menurut hemat penulis, hal itu terjadi disebabkan sumber daya manusia yang belum terpenuhi kemampuan keahlian di bidang pengetahuan akan kebutuhan terhadap pembuatan ketentuan hukum peraturan perundang-undangan yang diinginkan. Kondisi juga menjadi perhatian serius dan saling terkait untuk melakukan pengaturan ketertiban hukum pengelolaan eksplorasi pertambangan untuk mencapai kepastian hukum, hingga harus dilakukan upaya lebih serius lagi pada peningkatan kualifikasi sumber daya manusianya. Peningkatan keahlian dalam membuat peraturan perundang-undangan sangat diperlukan agar mampu meng-handle permasalahan dalam penegakan hukum terkait permasalahan pengelolaan eksplorasi pertambangan. Ini dimaksudkan agar celah-celah kelemahan peraturan perundang-undangan yang ada, tidak dijadikan pintu masuk untuk meraup keuntungan secara personal tanpa 
memikirkan lagi dampak negatif yang terjadi, terutama dampak lingkungan yang terjadi.

AMDAL sebagai dasar hukum dalam sistem perizinan kegiatan pertambangan akan menjadi hal paling urgent dan paling besar fungsinya dalam menjaga pelaksanaan pengolahan dan perlindungan lingkungan hidup Indonesia. Terlebih peran dari Pemerintah dan pemerintah Daerah sebagai tuan rumah sangat menentukan.

Tujuan akhir dari hal tersebut tentunya adalah untuk kepentingan dan keberlanjutan kehidupan manusia itu sendiri. Menjadi pemikiran serius bagaimana kekuatan sistem perizinan ini mampu menjaga hak-hak masyarakat terdampak, dan seberapa kuat sistem perizinan ini mampu mengakomodir kepentingan dan hak-hak yang dimiliki masyarakat terdampak, bagaimana kualitas perizinan yang dikeluarkan pemerintah daerah dalam hal menjaga hak-hak masyarakatnya.

\section{B. Rumusan Permasalahan}

Berdasarkan Latar belakang sebagaimana dijelaskan di atas, maka yang menjadi rumusan masalah adalah sebagai berikut:

1. Seperti apa kendali pemerintah daerah pada sistem perizinan terhadap izin lingkungan dan izin kegiatan pertambangan?

2. Seperti apa eksistensi AMDAL dalam sistem perizinan terhadap izin lingkungan dan izin kegiatan pertambangan?

3. Upaya apa yang dapat dilakukan oleh Pemerintah Daerah untuk menciptakan sistem perizinan pertambangan sehingga mampu menjaga hak-hak masyarakat terdampak?

\section{Metode Penelitian}

Penelitian ini merupakan penelitian hukum normatif disebut juga penelitian yuridis normatif atau bisa juga disebut sebagai penelitian doktrinal. Penulis meneliti bahan pustaka atau data sekunder yang mencakup bahan hukum primer, sekunder dan tersier.Data diperoleh dengan cara menelusuri dokumen peraturan perundang-undangan, buku, jurnal hukum, hasilhasil penelitian dan sumber lain yang bisa dipertanggung jawabkan validasinya. Analisis yang dilakukan bersifat kualitatif dengan menggunakan pendekatan analisis induktif.

\section{Pembahasan}

\section{Kendali pemerintah daerah terhadap sistem perizinan (izin lingkungan dan izin} kegiatan pertambangan).

Dinamisasi pengaturan masalah lingkungan hidup dan sumber daya alam sangatlah cepat. Indonesia telah mengalami fase tersebut dan konsep pembangunan yang awalnya berorientasi hanya kepada pembangunan, kini telah berubah orientasi. Bahwa ternyata ada objek lain yang tidak bisa diabaikan keberadaannya, yaitu lingkungan hidup. Konsep pembangunan yang dilaksanakan sekarang tidak cukup hanya mempertimbangkan perbandingan biayakeuntungan (cost-benefit ratio) saja, atau mekanisme pasar saja, juga memperhitungkan 
ongkos-ongkos sosial yang timbul (social cost). ${ }^{2}$

Substansi masalah pengelolaan Lingkungan Hidup dalam hukum lingkungan yang dipetakan dalam Undang-Undang Nomor 32 Tahun 2009 tentang Perlindungan dan Pengelolaan Lingkungan Hidup: ${ }^{3}$

1. Asas, tujuan dan ruang lingkup

2. Perencanaan, Pemanfaatan, Pengendalian dan Pemeliharaan

3. Pengelolaan B3 dan limbah B3

4. Sistem informasi

5. Tugas dan wewenang Pemerintah dan Pemerintah Daerah

6. Hak, kewajiban dan larangan

Berdasarkan ketentuan diatas maka sangatlah jelas terlihat bahwa salah satu substansi penting terkait masalah pengelolaan lingkungan hidup adalah terletak pada poin kelima yaitu tugas dan wewenang Pemerintah dan Pemerintah Daerah.Pemerintah dan Pemerintah daerah menjadi stake holder yang memegang peranan sangat besar. Perubahan pasal 18 UndangUndang Dasar Negara Republik Indonesia Tahun 1945, selanjutnya disebut UUD 1945 tepatnya pada perubahan kedua, terjadi perubahan tata cara penyelenggaraan pemerintahan,dari sentralistik menjadi desentralistik, berlakunya otonomi daerah (OTDA). Desentralisasi kewenangan yang kemudian diatur dalam Undang-Undang Nomor 32 Tahun 2004 tentang Pemerintahan Daerah, selanjutnya disebut UUPD semakin menguatkan peran Pemerintah Daerah dalam wujudnya sebagai Peraturan Daerah, selanjutnya disebut PERDA. ${ }^{4}$ Walaupun sebenarnya tidak semua berada ditangan PEMDA, ada beberapa pengelolaan yang dilaukan Pemerintah dalam hal ini adalah Kementrian Lingkungan Hidup, yaitu terkait kegiatan-kegiatan atau uasaha-usaha dengan kaliber besar.

Belakangan ini otonomi daerah dituding sebagai destroyer, pelaku perusak lingkungan dan sumber daya alam.Tudingan ini muncul bukan tanpa alasan, secara fakta empiris dan yurudis bahwa sejak munculnya sistem otonomi daerah ini kerusakan lingkungan dan sumber daya alam yang terjadi meningkat.Tentunya fakta ini sangat bertolak belakang dengan tujuan sebenarnya dari desentralisasi yang diamanatkan UUPD, terlebih terkait dengan masalah perlingdungan dan pengelolaan lingkungan hidup dan sumber daya alam.Dimana seharusnya kata "pemanfaatan" terhadap lingkungan hidup dan sumber daya alam, harus pula dibarengi dengan kata "pengelolaan dan perlindungan".Pada faktanya kedua kata terakhir diabaikan dan diletakkan dibarisan paling belakang.Hal itu pulalah yang terjadi pada ranah kegiatan pertambangan.

Dengan kewenangan baru yang dimilikiPemerintah Daerah yang merupakan amanat dari Pasal 18 UUD 1945, sejak ditetapkannya ketentuan itu tentunya sudah sangat banyak mengeluarkan PERDA-PERDA. Kurang lebih hampir berjalan selama 11 tahun dalam perjalannnya sejak tahun 2002. Termasuk tentunya Perda-perda yang mengatur masalah

Daud Silalahi, Masalah Pengelolaan Lingkungan Hidup, Edisi Ketiga, Alumni, Bandung, 2001, hlm. 19

Daud Silalahi, Masalah Pengelolaan Lingkungan Hidup (course materials). Lawencon Binding Centre, Bandung, 2013, hlm. 2

Ibid, hlm.3 
masalah pemanfataan sumber daya alam, pengutan pajak dan retribusi yang sebagian besarnya juga berkaitan dengan pemanfaatan sumber daya alam. Kebanyakan perda tersebut ditetapkan semata-mata hanya atas dasar economi benefit rumah tangga Pemerintah Daerah saja. Pendapatan Asli Daerah (PAD) menjadi rumusan terdepan dalam pelaksanaannya, sedangkan lingkungan hidup dibiaskan keberadannya. Maka jelas dengan kondisi tersebut kerusakan lingkungan akan pasti terjadi, semakin parah dan semakin hancur.

Suatu penelitian mengatakan, bahwa dari 287 perda di Jawa terkait dengan pengelolaan sumber daya alam, ternyata 148 diantaranya justru eksploitatif dan merusak lingkungan hidup, sehingga meningkatkan resiko bencana, hal ini tentunya sangat merugikan dan berpotensi merusak lingkungan hidup Indonesia. ${ }^{5}$ Itu hanya sebagian kecil saja, dimana yang menjadi sampel adalah Pulau Jawa.Apabila kita nasionalisasikan maka aka nada berapa ribu PERDA yang memilih nasib menjadi seperti itu.Pemerintah dalam hal ini Kementrian Dalam Negeri (Kemendagri) sejauh ini telah banyak memabatalkan perda-perda yang dianggap salah dan tidak layak. Namun sayangnya alasan yang digunakan bukan karena alasan kerusakan lingkungan yang disebabkannya melainkan karena alasan lain, yaitu alasan bahwa perda tersebut menghambat investasi, diskriminatif dan bertentangan dengan peraturan yang lebih tinggi.

\section{Eksistensi Amdal Dalam Sistem Perizinan (Izin Lingkungan Dan Izin Kegiatan Pertambangan).}

AMDAL merupakan studi aktifitas yang tersusun secara sistematik dan ilmiah dengan menggunakan teknik pendekatan yang bersifat interdisipliner bahkan multidisipliner, maka studi tersebut haruslah tersusun secara runtut dan komprehensif-integral (terpadu-lintas sektoral). ${ }^{6}$ Dalam sistem perizinan kegiatan pertambangan, maka AMDAL adalah hal mutlak yang harus ada.Posisi AMDAL dalam perizinan pertambangan adalah sebagai buku pintar pertama, diaman buku pintar pertama yang harus dimiliki oleh pemerintah sebelum fase pengolahan izin adalah Rencana tata Ruang/Wilayah Nasional dan PERDA RT/RW. Dengan PERDA RT/RW yang terintegrasi dan sinkron dengan Rencana tata Ruang/Wilayah Nasional dan renca kegiatan tambang sesuai dengan peruntukan Perda RTRW maka baru bisa kita masuki tahapan pengolahan AMDAL.

AMDAL dalam sistem perizinan berdasarkan UUPPLH: ${ }^{7}$

a. AMDAL sebagai informasi yang harus terbuka bagi masyarakat (BAB VIII, pasal 62 $\mathrm{UUPPLH}^{8}$ ).

\footnotetext{
BAPPENAS. Pembangunan yang Berorientasi kepada Daya Dukung dan Daya Tampung Lingkungan Hidup (Kasus Pulau Jawa), <http;//www.bappenas.go.id/ blog/?p=303> diakses pada tanggal 10 Agustus 2016 Pukul 13.40 WIB

6 Muhammad Erwin, Hukum Lingkungan : dalam sistem kebijaksanaan pembangunan Lingkungan Hidup, Edisi Ketiga, Refika Aditama, Bandung, 2007, hlm. 86

7 Daud Silalahi, Masalah Pengelolaan Lingkungan Hidup (course materials). Lawencon Binding Centre, Bandung, 2013, hlm. 5

8 Ayat (1). Pemerintah dan pemerintah daerah mengembangkan sistem informasi lingkungan hidup untuk mendukung pelaksanaan dan pengembangan kebijakan perlindungan dan pengelolaan lingkungan hidup. (2). Sistem informasi lingkungan hidup dilakukan secara terpadu dan terkoordinasi dan wajib dipublikasikan kepada masyarakat. (3). Sistem informasi lingkungan hidup paling sedikit memuat informasi mengenai status lingkungan hidup, peta rawan lingkungan hidup, dan informasi lingkungan hidup lain. (4). Ketentuan lebih lanjut mengenai sistem informasi lingkungan hidup diatur dengan Peraturan Menteri.
} 
b. AMDAL sebagai alat prediksi kemungkinan terjadinya dampak/ ongkos.

c. AMDAL sebagai alat pemantau/ RPL dan pengelolaan/ RKL kegiatan.

d. AMDAL sebagai legal evidence.

Dalam konteks perizinan kegiatan tambang, AMDAL akan menjadi tolak ukur yang mendasar secara spesifik, terkait tindak lanjut perizinan pertambangan tersebut. Maka AMDAL tiap-tiap jenis kegiatan pertambangan akan memiliki analisa ilmiah yang berbedabeda pula. AMDAL sebagai dasar pertama sistem perizin pertambangan akan berpengaruh besar terhadap izin lingkungan yang akan dikeluarkan oleh pemerintah. Kemudian akan berlanjut kepada izin usaha/kegiatan. Boleh dikatakan AMDAL adalah keran utama penentu baik buruknya kualitas izin lingkungan dan izin kegiatan.

Dasar hukum utama yang dijadikan sebagai senjata beroperasinya suatu kegiatan pertambangan adalah izin lingkungan dan izin kegiatan.Jadi, patutlah kiranya bahwa apabila terdapat kelemahan pada izin lingkungan atau izin kegiatan, yang pertamakali harus kita pertanyakan adalah AMDAL nya.Tetapi tidak menutup kemungkinan pula, bahwa AMDAL nya sudah baik tapi izin lingkungan atau izin kegiatannya yang tidak memiliki kesesuaian peruntukan berdasarkan ketentuan peraturan yang berlaku. Apabila hal tersebut terjadi, maka jelas bahwa pihak pemerinta yang memiliki itikat tidak baik. Berikut contoh kasus yang terjadi di Bengkulu.

"suatu perusahaan tambang batubara yang terletak diwilayah Bengkulu Tengah sudah beroperasi selama hampir 20 tahun. Ketika dilakukan penelitian terkait masalah dumping limbah perusahaan, maka penulis menemukan kejanggalan yang sangat luar biasa teledornya. Izin dumping limbah yang seharusnya dikeluarkan oleh Badan Lingkungan Hidup Kabupaten Bengkulu Tengah atas nama Kepala BLH Kabupaten Bengkulu Tengah, malah keluar dengan atas nama salah satu sekertaris bidang di BLH tersebut. Ini merupakan salah satu contoh praktik-praktik yang harus kita kawal pelaksanaannya.Halhal seperti itu akan menimbulkan konflik yang berbelit-belit kemudian hari, apabila terjadi masalah, yang ujung-ujungnya akan merugikan lingkungan dan masyarakat lagi.",9

AMDAL merupakan buku pintar yang mampu merangkup secara ilmiah kesemua fakta, baik fakta positif maupun fakta negatif dalam satu rangkuman mengenai akibat dari suatu kegiatan terhadap lingkungan hidup. Kesemua hal tersebut harus diketahui oleh masyarakat, dan harus disebarluaskan informasinya. Sehingga masyarakat juga akan ikut andil dalam memberi keputusan terhadap ajuan izin kegiatan yang direncanakan. Asas bertanggung jawab akan terlaksana secara tepat sasaran dan sesuai harapan kedepan nantinya. Manfaat secara konkrit dari AMDAL adalah bahwa AMDAL dapat membantu para pengusaha dalam menentukan alat-alat atau teknologi seperti apa yang akan digunakan, guna meraih benefit yang sesuai harapan tentunya juga dengan tidak merusak lingkungan dengan berupaya memperkecil dampak negatif lingkungan yang ditimbulkan.

Skripsi, David Aprizon Putra : Efektivitas Pelaksanaan Instrumen Dumping untuk Mencegah Terjadinya Pencemaran Limbah Batubara di Daerah Aliran Sungai (DAS) Sungai Bengkulu Menurut Undang-Undang Nomor 32 tahun 2009 tentang Perlindungan dan Pengelolaan Lingkungan Hidup, Fakultas Hukum Universitas Muhammadiyah Bengkulu, 2013. 
AMDAL akan menjadi fokus utama penulis dalam penjamabarn mini paper kali ini. Dalam mekanisme AMDAL dikenal adanya dokumen-dokumen yang harus dipenuhi, yakni Analisis Dampak Lingkungan (ANDAL), rencana pengelolaan lingkungan (RKL), rencana pemantauan lingkungan (RPL). PP Nomor 27 tahun 1999 tentang izin lingkungan menentukan bahwa pemrakarsa menyususn ANDAL, RKL dan RPL berdasarkan kerangka acuan yang telah mendapatkan keputusan instansi yang berkompeten. ANDAL digunakan sebagai telaah yang cermat mengenai dampak suatu kegiatan. Pada dasarnya ANDAL bertujuan untuk mengalisa suatu kegiatan yang berpotensi memberikan dampak terhadap lingkungan, yang juga sekaligus nantinya akan menjadi salah satu poin penting dalam pengambilan putusan terkait izin suatu kegiatan. RKL adalah uapaya pananganan dampak besar dan penting yang timbul sebagai akibat dari rencana kegiatan.Sedangkan RPL adalah upaya pemantauan komponen lingkungan yang terkena dampak besar dan penting sebagai akibat dari rencana kegiatan.

AMDAL sebagai legal evidence disini dimakdsudkan bahwa, AMDAL menjadi salah satu intrumen hukum yang ikut dalam kerangka hukum lingkungan. AMDAL akan berperan sangat sentral dalam penerapannya, karena AMDAL merupakan keran pembuka pertama terkait izin kegiatan pertambangan.Dalam kaitannya AMDAL dengan izin lingkungan, maka akan terlihat benang merah kedua instrumen tersebut dalam prosedural pelaksanaannya. Secara konseptual, izin lingkungan merupakan izin yang dikeluarkan apabila AMDAL-nya sudah keluar.Jadi maksudnya bahwa, izin lingkungan merupakan perpanjangan tangan sekaligus hasil dari AMDAL yang diterima. Jika AMDALnya ditolak, maka jelas izin lingkungannya tidak akan keluar.

Secara ilmiah prosedur pelaksanaan AMDAL memiliki 7 tahapan. Dimana setiap tahapannya akan bersinggungan dengan disiplin ilmu-ilmu lainnya sebagaimana penulis jelaskan pada bagian sebelumnya. Ini akan menjadi bukti, bahwa AMDAL memiliki metode ilmiah sendiri dalam setiap jenis kegiatan/usaha. Dalam Peraturan Pemerintah Nomor 27 tahun 2012 tentang Izin Lingkungan Pasal ayat (1), mengamatkan secara prosedural penyusunan dokumen AMDAL :

(1) Penyusunan Amdal sebagaimana dimaksud dalam Pasal 4 ayat (1) dituangkan ke dalam dokumen Amdal yang terdiri atas:
a. Kerangka Acuan;
b. Andal; dan
c. RKL-RPL.

Itu merupakan prosedural ilmiah yang diamatkan oleh PP tersebut.Secara umum poinpoin yang dimaksud adalah ketiga poin tersebut. Penulis akan mencoba menjelaskan secara lebih rinci tahapan-tahapan dalam pelaksanaan AMDAL :

a. Penapisan (screening)

AMDAL didahuli dengan penapisan (sreening) apakah kegiatan tersebut memerlukan AMDAL atau tidak. Jika memerlukan AMDAL maka sesuai dengan amanat 
pasal 3 ayat (1) PP Nomor 27 tahun $1999^{10}$ yang menyatakan bahwa setiap rencana kegiatan yang mempunyai dampak besar dan penting terhadap lingkungan wajib dibuatkan informasi lingkungannya sesuai dengan peruntukkan yang dimaksud oleh PP ini. Dalam menetukan dampak penting suatu kegiatan terhadap lingkungan hidup berdasarkan Keputusan BAPEDAL No. KEP-056 tahun1994 tentang pedoman mengenai ukuran dampak penting yaitu :

1) Jumlah manusia yang terkena dampak;

2) Luas wilayah persebaran dampak;

3) Lamanya dampak berlangsung;

4) Intensitas dampak;

5) Banyaknya komponen lingkungan lain yang terkena dampak;

6) Sifat komulatif dampak;

7) Berbalik atau tidak berbaliknya dampak.

Faktor-faktor yang menetukan adanya dampak penting tersebut didasarkan pada pengetahuan ilmiah yang ada.Tentunya dalam perkembangan pulalah, faktor-faktor tersebut bisa berubah.

b. Pelingkupan (scoping)

Diartikan sebagai pembatasan ruang lingkup pelaksanaan ANDAL.Agar ANDAL yang dihasilkan memiliki data dan informasi yang relevan sesuai dengan rencana kegiatan pertambangan yang direncanakan.

c. Kerangka Acuan

Kerangka acuan merupakan uraian tugas yang harus dilaksanakan dalam studi ANDAL. Kerangka acuan dijabarkan dari perlingkupan sehingga kerangka acuan memuat tugas-tugas yang relevan dengan dampak penting.Dengan kerangka acuan yang demikian itu, studi ANDAL menjadi terfokus pada dampak penting.

\section{d. Analisis Dampak Lingkungan (ANDAL)}

ANDAL adalah telaah secara cermat dan mendalam tentang dampak besar penting suatu rencana usaha dan/atau kegiatan. ${ }^{11}$ Pedoman umum penyusunan dokumen ANDAL berfungsi sebagai acuan bagi penyusunan Pedoman Teknis Penyusunan ANDAL, atau sebagai dasar penyusunan ANDAL bilamana Pedoman Teknis Penyusunan ANDAL usaha atau kegiatan yang bersangkutan belum ditetapkan. Pedoman penyusunan ANDAL

\footnotetext{
${ }^{10}$ Usaha dan/atau kegiatan yang kemungkinan dapat menimbulkan dampak besar dan penting terhadap lingkungan hidup meliputi : a.pengubahan bentuk lahan dan bentang alam;b.eksploitasi sumber daya alam baik yangterbaharui maupun yang tak terbaharui;c.proses dan kegiatan yang secara potensialdapat menimbulkan pemborosan, pencemaran dan kerusakan lingkungan hidup, sertakemerosotan sumber daya alam dalam pemanfaatannya;d.proses dan kegiatan yang hasilnya dapatmempengaruhi lingkungan alam, lingkungan buatan, serta lingkungan sosial danbudaya;e.proses dan kegiatan yang hasilnya akan dapatmempengaruhi pelestarian kawasan konservasi sumber daya alam dan/atauperlindungan cagar budaya; f.introduksi jenis tumbuh-tumbuhan,jenis hewan, dan jasad renik;g.pembuatan dan penggunaan bahan hayati dan non-hayati; h.penerapan teknologi yang diperkirakanmempunyai potensi besar untuk mempengaruhi lingkungan hidup; i.kegiatan yang mempunyai risiko tinggi, dan/atau mempengaruhi pertahanan negara.

11 Pasal 1 ayat (4) Peraturan Pemerintah Nomor 27 tahun 1999 tentang Analisis Mengenai Dampak Lingkungan Hidup.
} 
berlaku pula bagi keperluan penyusunan AMDAL kegiatan terpadu/multisektor, AMDAL kawasan dan AMDAL regional.

e. Rencana Pengelolaan Lingkungan (RKL)

Dokumen Rencana Pengelolaan Lingkungan merupakan dokumen yang memuat upaya-upaya mencegah, mengendalikan dan menaggulangi dampak penting lingkungan yang timbul sebagai akibat dari dari suatu rencana usaha atau kegiatan.

f. Rencana Pemantauan Lingkungan (RPL)

Dokumen Rencana Pemantauan Lingkungan (RPL) merupakan rencana yang disusun berkenanaan dengan pengulangan pengukuran komponen atau parameter lingkungan pada waktu-waktu tertentu, guna mengetahui adanya perubahan - perubahan lingkungan karena pengaruh kegiatan atau usaha (proyek) tersebut.

g. Pelaporan

Pada akhirnya, setelah semua tahapan diatas selesai, ditulislah hasil penelitian dalam sebuah laporan. Pada umumnya laporan ini terbagi menjadi 3 bagian penjelasan, yang pertama yaitu ringkasan eksekutif (executive summary), laporan utama (main report) dan lampiran (appendix).

Pada masing-masing tahapan diatas, maka akan selalu bersinggungan kepentingan disiplin-disilin ilmu lainnya, dengan Ilmu Hukum dan Ilmu Hukum Lingkungan menjadi basis benang merah perjalannya. Ilmu Lingkungan adalah dasar utama yang menjadi patokan ilmu hukum dan ilmu hukum lingkungan dalam setiap pengambilan keputusan dan kebijakan yang akan diberlakukan secara hukum nantinya. Teknologi akan menjadi porsi terbesar dalam aplikasi dilapangan, ia akan bericara secara matematis dalam perhitungan penggunaan teknologi apa yang sesuai. Ilmu fisika,kimia akan berbicara pada tataran teknis pula yang akan erat kaitannya dengan teknologi. Ilmu Ekonomi akan menjadi poin dasar yang akan mempengaruhi para pemangku kepentingan (stake holders) dalam merencanakan di awal, untung rugi dari satu keputusan kebijakan yang dibuat bagi daerah sebagai pemilik area pertambangan dan pengusaha yang datang di daerah pertambangan milik rakyat Indonesia pada daerah pertambangan yang dikelola. Kesemua disiplin ilmu itu akan berafiliasi menjadi satu kesatuan yang bertujuan untuk meraih keuntungan ekonomi dengan meminimalkan dampang kerugian lingkungan, dan itulah sebenarnya tujuan utama dari perlindungan dan pengelolaan lingkungan hidup Indonesia dengan paying hukumnya adalah Undang-Undang Nomor 32 tentang Perlindungan dan Pengelolaan Lingkungan Hidup.

\section{Upaya Yang Bisa Dilakukan Oleh Pemerintah Daerah Untuk Menciptakan Sistem Perizinan Pertambangan Sehingga Mampu Menjaga Hak-Hak Masyarakat Terdampak.}

Bola sudah ada ditangan daerah, seperti ulasan pada bab sebelumnya, yaitu terkait lingkup sistem hukum perizinan dimana rumpun dasar yang menjadi pilar utamanya adalah : Kajian lingkungan Hidup Strategis (KLHS), Tata Ruang/Wilayah (RT/RW), Analisis Mengenai Dampak Lingkungan (AMDAL), izin lingkungan dan izin kegiatan. Penulis akan 
mencoba membuat suatu bagan yang menjadi gambaran akan eksistensi kelima instrumen perizinan tersebut:

\section{Bagan 2. \\ Eksistensi Lima Instrumen Perizinan Pertambangan}

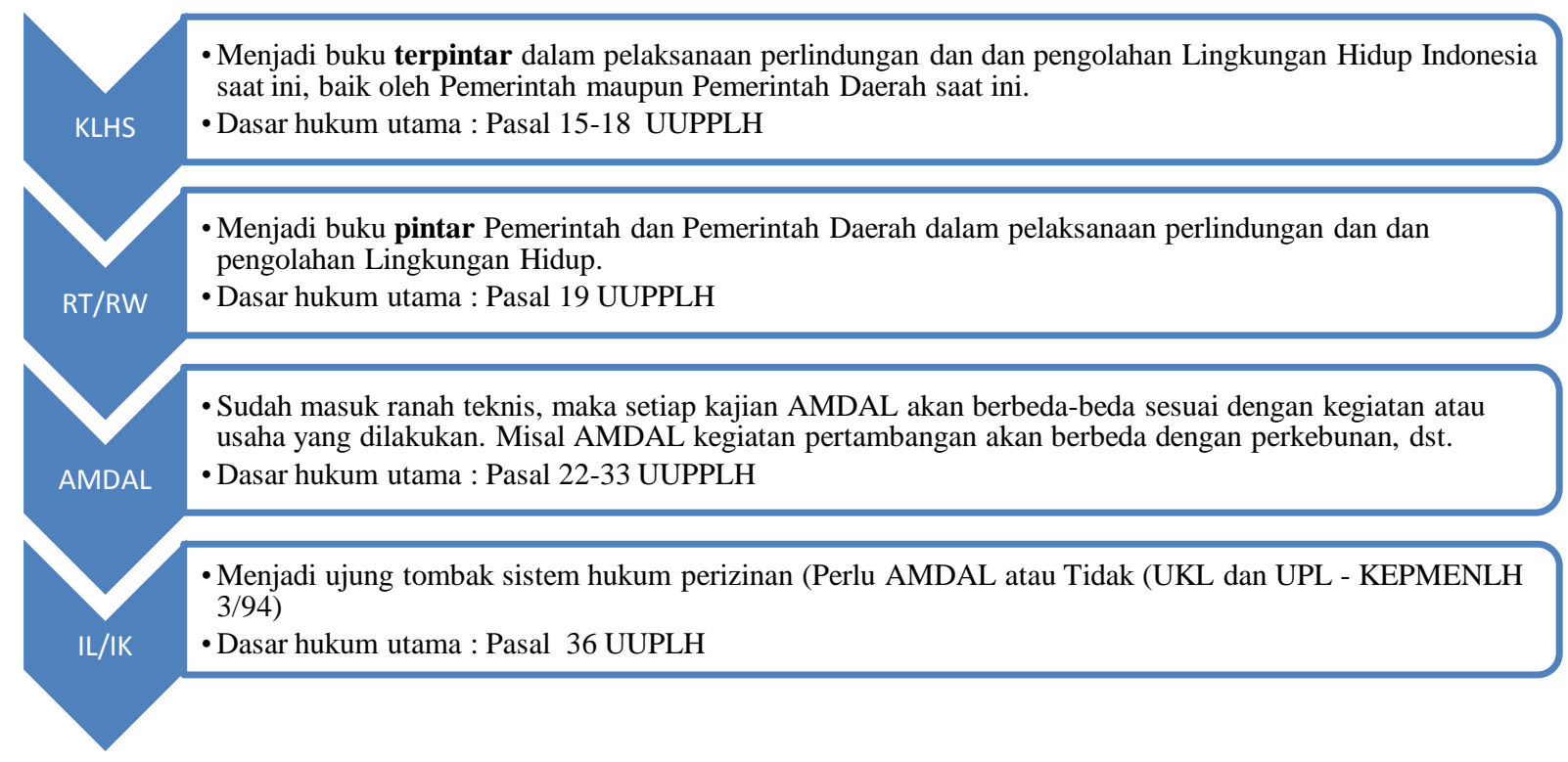

Dari gambaran diatas maka kita dapat melihat secara umum perjalanan dan proses yang harus dilalui dan dilakukan oleh Pemerintah Daerah dalam proses sistem hukum perizinan lingkungan hidup. Dimulai dari KLHS sampai dengan Izin Lingkungan dan izin Kegiatan akan melalui proses yuridis dan ilmiah tentunya dalam proses pelaksanaannya. Terlebih AMDAL, sebagi salah satu instrument penting yang menjadi peletakkan batu utama suatu kegiatan atau usaha dalam upaya menginventarisasi seacara pintar dan ilmiah kesemua lingkup kegiatan atau usaha yang akan dilaksanakaan nantinya. Kemudian AMDAL ini akan menjadi rujukan pertama dan utama apabila dikemudian hari mungkin akan terjadi suatu permasalahannya. Kesempurnaan AMDAL akan menjadi penolong yang bijak nantinya dikemudian hari. Undang-Undang Nomor 32 tahun 2009 tentang Perlindungan dan Pengelolaan Lingkungan Hidup sudah mengatur sedemikian rupa kesemua aspek perlindungan dan pengelolaan lingkungan hidup. Termasuk didalamnya adalah terkait masalah perizinan ini.

PERDA RT/RW tidak berdiri sendiri, ada Rencana Tata Ruang/ Wilayah Nasional. Dalam konteks perizinan kegiatan tambang ini, maka kedua aturan hukum ini sangat berkaitan erat. Sebagaimana terlihat akan keterkaitan tersebut nampak jelas dalam Pasal 9 UndangUndang Nomor 4 tahun 2009 tentang Undang-Undang Pertambangan Minerba :

(1). WP sebagai bagian dari tata ruang nasional merupakan landasan bagi penetapan kegiatan pertambangan. 
(2). WP sebagaimana dimaksud pada ayat (1) ditetapkan oleh Pemerintah setelah berkoordinasi dengan pemerintah daerah dan berkonsultasi dengan Dewan Perwakilan Rakyat Republik Indonesia.

Diperlukan sinkronisasi PERDA RTRW dengan Rencana Tata Ruang/ Wilayah Nasional. Hal tersebut akan menjadi satu kerangka fikir yang satu visi dan misi dalam mengawal pelaksanaan perlidungan dan pengolahan lingkungan hidup Indonesia. Pemerintah daerah harus tunduk kepada pemerintah pusat, tidak boleh semena-mena mengatur rumah tangga sendiri tanpa melihat peraturan perundang-undangan nasional lain yang juga ikut mengatur. Sebenarnya sekup pembahasan ini seringkali terjadi polemik. Polemik yang terjadi adalah terkait kekuatan penguasaan oleh pemerintah daerah yang dipayungi oleh kekuatan hukum otonomi daerah itu sendiri. Banyak pemerintah daerah yang menjadi semaunya sendiri, tidak mau ikut aturan nasional lagi dengan memanfaatkan celah-celah kelemahan peraturan perundang-undangan. Hal inilah yang sekarang banyak berkembang, pemerintah pusat seakan tidak berdaya melihat perkembangan ini.

Setelah memiliki PERDA Rencana Tata Ruang/Wilayah (PERDA RT/RW) yang baik, maka implementasi masalah perizinan, termasuk masalah perizinan pertambangan akan bisa linier semangatnya. Setiap izin pengelolaan lingkungan hidup (izin lingkungan dan izin kegiatan) tidak boleh bertentangan dengan ketentuan PERDA RTRW yang telah ada. Salah satu yang harus diperhatikan adalah terkait jaminan hak-hak masyarakat terdampak, dalam UU 32/2009 jaminan tersebut sangat jelas diatur dalam pasal 70 ayat (1) :

Masyarakat memiliki hak dan kesempatan yang sama dan seluas-luasnya untuk berperan aktif dalam perlindungan dan pengelolaan lingkungan hidup.

Artinya bahwa, ada jaminan secara legal yang diberikan UU 32/2009 ini terkait perlindungan hak masyarakat dalam hal peran aktif mengelola dan melindungi lingkungan hidup. Dalam proses pemberian izin, partisipasi masyarakat menjadi salah satu faktor penting dan penentu, apakah masyarakat setuju atau tidak. Tahapan ini merupakan proses terpenting, pemerintah dan pihak pengaju izin harus benar-benar mengakomodasi saran, masukkan dan tuntutan masyarakat tersebut, agar kemudian dapet mengahsilkan instrument izin yang benarbenar disepakati para pihak secara baik. Sehingga kemudian dalam pelaksanaannya, proses pengawasan, chek and balanches bisa terwujud.

Apabila amanat undang-undang benar-benar dilaksanakan dalam pelaksanaan Otonomi Daerah, maka otonomi daerah akan menjadi senjata ampuh dalam proses membangun negara ini. Tetapi dalam pelaksanaannya, banyak perilaku-perilaku para stake holdersyang keluar jalur. Izin lingkungan yang seharusnya menambah kekuatan hukum lingkungan di daerah tersebut, malah menjadi alat oknum-oknum untuk mencari keuntungan pribadi.Izin lingkungan yang seharusnya sinkron dengan peratu-peraturan yang lainnya, malah menjadi pembentur yang merusak tatanan aturan hukum lingkungan didaerah tersebut. 


\section{E. Penutup}

Berdasarkan penjabaran diatas dan sesuai dengan ketiga tujuan dari penulisan mini paper ini maka penulis menyimpulkan:

1. Pemerintah Daerah memiliki kewenangan kendali yang sangat penting dalam pelaksnaan perlindungan dan pengelolaan lingkungan hidup. Dengan kondisi yang terjadi saat ini, maka kita perlu upaya besar dalam mengatasi kebobrokannya sistem perizinan terkait pengelolaan sumber daya alam. Sumber Daya Manusia menjadi kata kunci dalam hal upaya perubahan tersebut perlu ditingkatkan kualifikasinya.

2. AMDAL memiliki metode ilmiah tersendiri dalam pelaksanaanya, dengan 7 tahapan: Penapisan (screening), Pelingkupan (scoping), Kerangka Acuan Analisis Dampak Lingkungan (ANDAL), Rencana Pengelolaan Lingkungan (RKL), Rencana Pemantauan Lingkungan (RPL) dan Pelaporan. Dimana ketujuh tahapan tersebut terintegrasi dan terafiliasi dengan pengaruh disiplin ilmu ilmiah dengan tupoksi (pengaruh, fungsi dan peran) masing-masing disiplin ilmu tersebut berbeda-beda.

3. Potensi kandungan kekayaan alam dan keputusan kebijakan ada di daerah sebagai implementasi Otonomi Daerah, maka pemerintah daerah harus melakukan pelaksanaan sistem perizinan pertambangan yang mampu menjamin hak masyarakat, penguatan yang utama adalah dengan melibatkan msyarakat dalam setiap proses pembuatannya ketentuan peraturan perundang-undangan, juga di dalam UU 32/2009 telah menjamin hak masyarakat untuk itu, yang kemudian menjadi hal penting adalah terkait pengawasan dan penegakan hukum.

\section{Daftar Pustaka}

\section{Buku-buku :}

Daud Silalahi, Masalah Pengelolaan Lingkungan Hidup (course materials). Lawencon Binding Centre, Bandung, 2013.

Daud Silalahi, Masalah Pengelolaan Lingkungan Hidup, Edisi Ketiga, Alumni, Bandung, 2001.

Dewan Perwakilan Daerah Republik Indonesia, Kompleksitas Administrasi Pemerintahan Dengan Pendekatan Kebijakan Regional, DPR RI, Jakarta, 2011.

Muhammad Erwin, Hukum Lingkungan : dalam sistem kebijaksanaan pembangunan Lingkungan Hidup Edisi Ketiga, Refika Aditama, Bandung, 2007.

\section{Penelitian :}

Skripsi, David Aprizon Putra : Efektivitas Pelaksanaan Instrumen Dumping untuk Mencegah Terjadinya Pencemaran Limbah Batubara di Daerah Aliran Sungai (DAS) Sungai 
Bengkulu Menurut Undang-Undang Nomor 32 tahun 2009 tentang Perlindungan dan Pengelolaan Lingkungan Hidup, Fakultas Hukum Universitas Muhammadiyah Bengkulu, 2013.

\section{Internet :}

BAPPENAS. Pembangunan yang Berorientasi kepada Daya Dukung dan Daya Tampung Lingkungan Hidup (Kasus Pulau Jawa), <http;//www.bappenas.go.id/blog/?p=303>

\section{Peraturan Perundang-undangan :}

Undang-Undang Dasar Negara Republik Indonesia Tahun 1945.

Undang-Undang Nomor 32 Tahun 2004 tentang Pemerintahan Daerah.

Undang-Undang Nomor 4 tahun 2009 tentang Pertambangan Minerba.

Undang-Undang Nomor 32 Tahun 2009 tentang Perlindungan dan Pengelolaan Lingkungan Hidup.

Peraturan Pemerintah Nomor 27 tahun 1999 tentang Analisis Mengenai Dampak Lingkungan Hidup.

Peraturan Pemerintah Nomor 27 tahun 2012 tentang Izin Lingkungan.

Keputusan BAPEDAL No. KEP-056 tahun1994 tentang pedoman mengenai ukuran dampak penting 